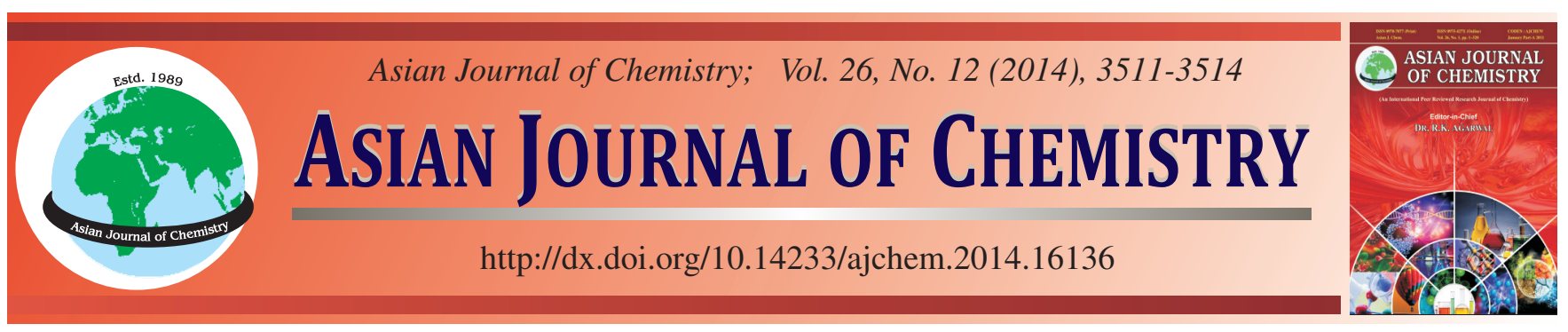

\title{
Content Analysis of Flavonoids in the Stems and Roots of Acanthopanax Species in Different Countries
}

\author{
Jeong Min Lee, Dong Gu Lee, Jongkee Kim and Sanghyun LeE*
}

Department of Integrative Plant Science, Chung-Ang University, Anseong 456-756, Republic of Korea

*Corresponding author: Fax: +82 31 6764686; Tel: +82 31 6704688; E-mail: slee@cau.ac.kr

\begin{abstract}
Content analysis of flavonoids in the stems and roots of Acanthopanax species (A. divaricatus, A. koreanum, A. senticosus and A. sessiliflorus) in different nations was conducted by high performance liquid chromatography. In the stems and roots of Acanthopanax species, the contents of rutin, hyperin, afzelin, quercetin and kaempferol were $0.024-0.326$ and $0.059-0.531,0.391-4.256$ and $0.957-$ $3.517,0.935-10.572$ and $1.019-1.185,0.375-0.885$ and $0.394-0.501,0.193-0.872$ and $0.179-0.500 \mathrm{mg} / \mathrm{g}$, respectively. Total content of flavonoids in the stems and roots was highest in A. senticosus (Mt. Baekdu) and A. sessiliflorus (Gongju), respectively. Also, hyperin and afzelin were the most abundant compounds in the roots and stems of Acanthopanax species, respectively. This result will provide useful information in the application of these flavonoids from Acanthopanax species in the nutraceutical, pharmaceutical and cosmeceutical areas.

Keywords: Acanthopanax species, Flavonoid, Analysis, Reflux.
\end{abstract}

\section{INTRODUCTION}

Acanthopanax species, belonging to the family Araliaceae, are perennial herbaceous species. The dried roots and stem barks of Acanthopanax species have been used as a sedative and tonic to treat rheumatism, liver disease and diabetes, chronic bronchitis, stress, ischemic heart disease, tumor, hypertension and gastric ulcers ${ }^{1-4}$. The methanolic and aqueous extracts of the rhizomes of $A$. senticosus have trophic and beneficial effects, such as neuronal protection, as shown in an in vitro assay system for Alzheimer's disease ${ }^{5}$. Acanthopanax species have been widely used as health supplements because they have ginseng-like biological activities and are a famous tonic in Korea ${ }^{6}$.

Flavonoids such as afzelin, antoside, isoquercitrin, hyperin, kaempferol, quercitrin and rutin have been previously isolated from Acanthopanax species ${ }^{7-11}$. Flavonoids have been used as natural antioxidants and for their health-promoting properties in humans ${ }^{12}$. Flavonoids having above biological activities are important compounds in Acanthopanax species. Until now, many studies have been reported on the analysis of triterpenoids, lignans and phenylpropanoids constituents of Acanthopanax ${ }^{13-16}$, but there have been few reports on flavonoid analysis in Acanthopanax species.

In this study, content analysis of flavonoids (rutin, hyperin, afzelin, quercetin and kaempferol) in the stems and roots of Acanthopanax species in different nations (South Korea, North
Korea, Russia and China) was conducted using an efficient and simple high performance liquid chromatography (HPLC) method.

\section{EXPERIMENTAL}

The stems and roots of Acanthopanax species (A. divaricatus, A. koreanum, A. senticosus and A. sessiliflorus) in different nations (Gongju and Jungseon, South Korea; Mt. Baekdu, North Korea; Khabarovsk, Russia; Yanbian, China) were collected and botanically identified by Prof. S. H. Cho, Gongju National University of Education, Korea.

HPLC chromatograms were recorded with a Waters Breeze system (MA, USA) equipped with a Waters 1525 binary HPLC pump and 2489 system UV/VIS detector. A Discovery ${ }^{\circledR}$ $\mathrm{C} 18(4.6 \times 250 \mathrm{~mm}, 5 \mu \mathrm{m})$ column was purchased from SigmaAldrich Co. (PA, USA). Water and acetonitrile used in this research were of HPLC grade and all other reagents were of analytical grade.

Preparation of standard flavonoids: Compounds 1-5 were isolated by repeated column chromatography as reported previously. Compound $\mathbf{1}$ was isolated from the ethyl acetate fraction of Fagopyrum tataricum ${ }^{17}$. Compound $\mathbf{2}$ was isolated from the ethyl acetate fraction of Acanthopanax chiisanensis ${ }^{18}$. Compounds $\mathbf{3}$ and $\mathbf{5}$ were isolated from the ethyl acetate fraction of Rhododendron mucronulatum for albiflorum ${ }^{19}$. Compound 4 was isolated from the butanolic fraction of Vaccinium koreanum $^{18}$. 
Sample preparation: For analysis of flavonoids (rutin, hyperin, afzelin, quercetin and kaempferol) in Acanthopanax species (A. divaricatus, A. koreanum, A. senticosus and A. sessiliflorus) in different nations, $50 \mathrm{~g}$ of each plant part (the stems and roots) from Acanthopanax species was extracted with $50 \% \mathrm{MeOH}(3 \times 100 \mathrm{~mL})$ by reflux and evaporated in vacuo. The residue was dissolved in $1 \mathrm{~mL}$ of $\mathrm{MeOH}$ and filtered with a $0.45 \mu \mathrm{m}$ filter. The resulting solution was used for HPLC analysis.

HPLC conditions: HPLC separation of flavonoids for qualitative and quantitative analysis was performed using a reverse phase system. A Discovery ${ }^{\circledR} \mathrm{C} 18(4.6 \times 250 \mathrm{~mm}, 5 \mu \mathrm{m})$ column was used with a mobile phase consisting of water $(0.1 \%$ acetic acid) and acetonitrile. The elution program was a gradient solvent system (water : acetonitrile $=90: 10$ to $60: 40$ for $60 \mathrm{~min}$ ). UV detection was conducted at $350 \mathrm{~nm}$. The injection volume was $10 \mu \mathrm{L}$ and the flow rate was $1 \mathrm{~mL} / \mathrm{min}$. All injections were performed in triplicate.

Calibration curve: A stock solution $(1 \mathrm{mg} / \mathrm{mL})$ of each flavonoid was prepared in $\mathrm{MeOH}$, successively reducing the solution content to $50 \%$ to create different concentrations. The contents of the analytes were determined from the corresponding calibration curves. The calibration functions of the flavonoids were calculated using the peak area $(\mathrm{Y})$, concentration $(\mathrm{X}, \mu \mathrm{g} / 10 \mu \mathrm{L})$ and mean values $(\mathrm{n}=4) \pm$ standard deviation.

Statistical analysis: Data of each sample was expressed as mean \pm S.D. ANOVA using the SAS Enterprise Guide software was calculated and the significance between the mean of each group were analyzed using Duncan's multiple test.

\section{RESULTS AND DISCUSSION}

Content analysis of flavonoids in the stems and roots of Acanthopanax species in different nations was conducted by HPLC. Compounds 1-5 (Fig. 1) were previously isolated from A. koreanum, A. divaricatus, A. chiisanensis and A. sciadophylloides $^{8-10,18}$.<smiles>[R2]c1cc(-c2oc3cc(O)cc(O)c3c(=O)c2O)ccc1O</smiles>

\begin{tabular}{lll}
\hline Compound & $\mathrm{R}_{1}$ & $\mathrm{R}_{2}$ \\
\hline $\mathbf{1}$ & Rutinose & $\mathrm{OH}$ \\
$\mathbf{2}$ & Galactose & $\mathrm{OH}$ \\
$\mathbf{3}$ & Rhamnose & $\mathrm{H}$ \\
$\mathbf{4}$ & $\mathrm{H}$ & $\mathrm{OH}$ \\
$\mathbf{5}$ & $\mathrm{H}$ & $\mathrm{H}$ \\
\hline
\end{tabular}

Fig. 1. Chemical structures of compounds $\mathbf{1 - 5}$

HPLC separation of flavonoids for qualitative and quantitative analysis was performed using a reverse phase system. HPLC condition was developed for the analysis of five standard flavonoids with good linearity $\left(r^{2}=0.9999\right)^{20}$. The content of five standard flavonoids in Acanthopanax species was investigated in different nations. The HPLC chromatograms of standard flavonoids and $50 \%$ methanolic extracts of Acanthopanax species were shown in Fig. 2. In the stems of Acanthopanax species, the contents of rutin (1), hyperin (2), afzelin (3), quercetin (4) and kaempferol (5) were 0.024-0.326, 0.391$4.256,0.935-10.572,0.375-0.885$ and $0.193-0.872 \mathrm{mg} / \mathrm{g}$, respectively. Also, the total content of flavonoids was 2.264$11.941 \mathrm{mg} / \mathrm{g}$. In our results, the most abundant flavonoid in the stems was afzelin $(47.994 \mathrm{mg} / \mathrm{g})$ and the total content of flavonoids was highest in A. senticosus from Mt. Baekdu (11.941 mg/g) (Table-1). In the roots of Acanthopanax species, the contents of rutin (1), hyperin (2), afzelin (3), quercetin (4) and kaempferol (5) were 0.059-0.531, 0.957-3.517, 1.019$1.185,0.394-0.501$ and $0.179-0.500 \mathrm{mg} / \mathrm{g}$, respectively. Also, the total content of flavonoids was $2.913-6.106 \mathrm{mg} / \mathrm{g}$. In present results, the most abundant flavonoid in the roots was hyperin $(18.274 \mathrm{mg} / \mathrm{g})$ and the total content of flavonoids was highest in A. sessiliflorus from Gongju (6.106 mg/g) (Table-2).
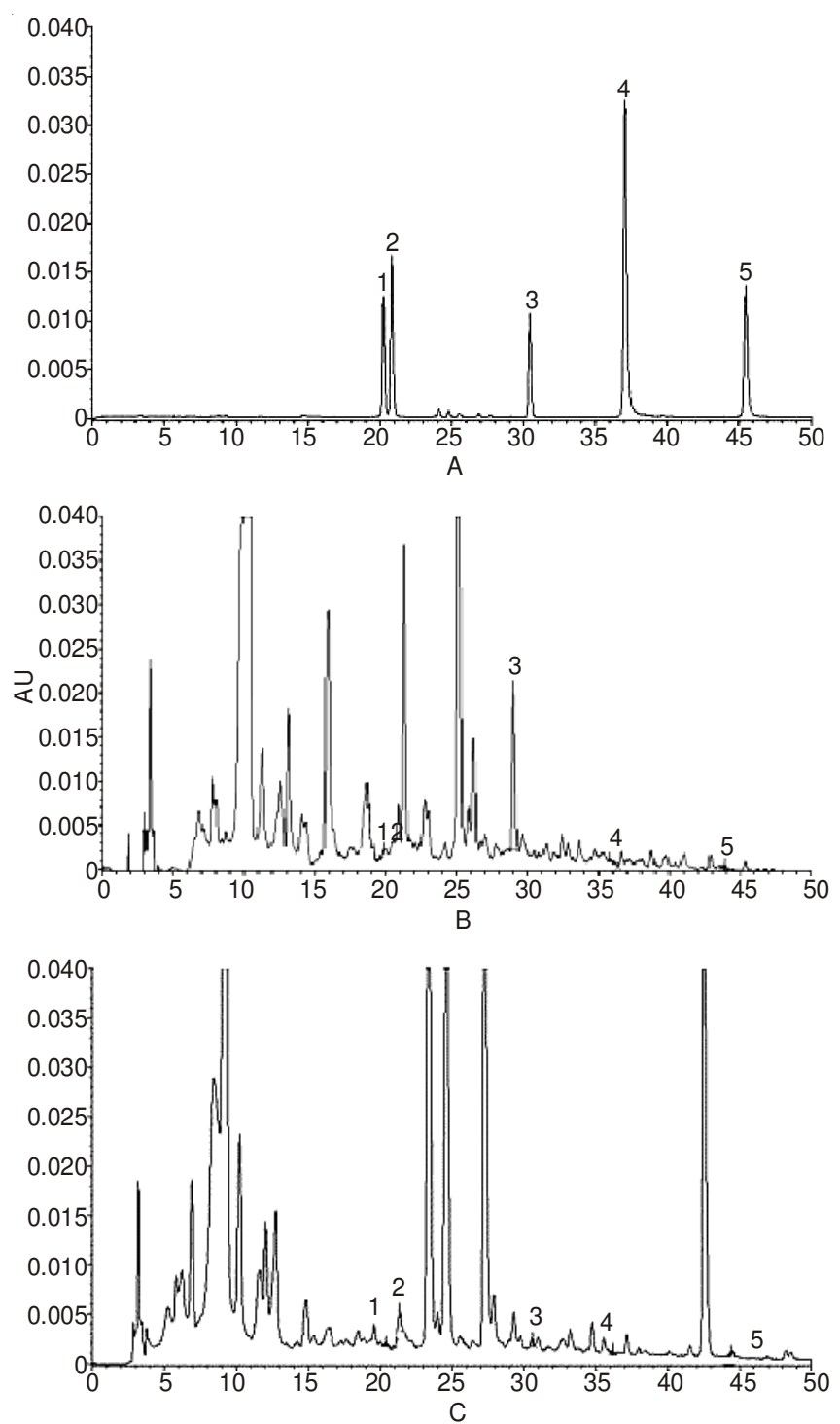

Fig. 2. HPLC chromatograms of standard flavonoids (A) and the $50 \%$ $\mathrm{MeOH}$ extracts of $A$. senticosus stems (B) from Mt. Baekdu and $A$. divaricatus roots (C) from Gongju (1, rutin; 2, hyperin; 3, afzelin; 4, quercetin; 5, kaempferol 
TABLE-1

CONTENTS OF COMPOUNDS 1-5 IN THE 50 \% METHANOLIC EXTRACTS OF THE STEMS OF Acanthopanax SPECIES

\begin{tabular}{|c|c|c|c|c|c|c|}
\hline \multirow{2}{*}{ Sample } & \multicolumn{6}{|c|}{ Content $(\mathrm{mg} / \mathrm{g})$} \\
\hline & 1 & 2 & 3 & 4 & 5 & Total \\
\hline A. koreanum from Gongju & $0.062 \pm 0.008^{\mathrm{d}}$ & $0.450 \pm 0.010^{\mathrm{e}}$ & $0.935 \pm 0.028^{f}$ & $0.412 \pm 0.001^{b}$ & $0.405 \pm 0.007^{\mathrm{c}}$ & $2.264 \pm 0.054$ \\
\hline A. divaricatus from Gongju & Trace & $4.256 \pm 0.137^{\mathrm{a}}$ & $1.105 \pm 0.059^{f}$ & $0.885 \pm 0.009^{\mathrm{a}}$ & $0.628 \pm 0.020^{\mathrm{b}}$ & $6.874 \pm 0.225$ \\
\hline A. sessiliflorus from Gongju & $0.029 \pm 0.005^{\mathrm{e}}$ & $0.807 \pm 0.011^{\mathrm{d}}$ & $3.030 \pm 0.053^{\mathrm{e}}$ & $0.382 \pm 0.001^{\mathrm{d}}$ & $0.193 \pm 0.001^{\mathrm{f}}$ & $4.441 \pm 0.071$ \\
\hline A. senticosus from Gongju & $0.255 \pm 0.007^{\mathrm{b}}$ & $1.140 \pm 0.033^{c}$ & $5.830 \pm 0.013^{d}$ & $0.388 \pm 0.001^{\mathrm{d}}$ & $0.402 \pm 0.004^{\mathrm{c}}$ & $8.015 \pm 0.058$ \\
\hline A. senticosus from Jungseon & $0.326 \pm 0.014^{\mathrm{a}}$ & $0.391 \pm 0.003^{\mathrm{e}}$ & $9.798 \pm 0.329^{a}$ & $0.393 \pm 0.002^{c}$ & $0.872 \pm 0.016^{\mathrm{a}}$ & $11.780 \pm 0.364$ \\
\hline A. senticosus from Mt. Baekdu & $0.024 \pm 0.003^{e}$ & $0.664 \pm 0.008^{d}$ & $10.572 \pm 0.323^{a}$ & $0.386 \pm 0.001^{d}$ & $0.295 \pm 0.005^{\mathrm{e}}$ & $11.941 \pm 0.340$ \\
\hline A. senticosus from Khabarovsk & $0.095 \pm 0.009^{c}$ & $1.715 \pm 0.052^{b}$ & $8.647 \pm 0.255^{b}$ & $0.380 \pm 0.001^{\mathrm{d}, \mathrm{e}}$ & $0.342 \pm 0.010^{d}$ & $11.179 \pm 0.327$ \\
\hline A. senticosus from Yanbian & $0.065 \pm 0.003^{\mathrm{d}}$ & $0.468 \pm 0.006^{\mathrm{e}}$ & $8.077 \pm 0.331^{\mathrm{c}}$ & $0.375 \pm 0.001^{\mathrm{e}}$ & $0.398 \pm 0.003^{c}$ & $9.383 \pm 0.344$ \\
\hline Total & $0.856 \pm 0.049$ & $9.891 \pm 0.260$ & $47.994 \pm 1.391$ & $3.601 \pm 0.017$ & $3.535 \pm 0.066$ & - \\
\hline
\end{tabular}

TABLE-2

CONTENTS OF COMPOUNDS 1-5 IN THE $50 \%$ METHANOLIC EXTRACTS OF THE ROOTS OF Acanthopanax SPECIES

\begin{tabular}{|c|c|c|c|c|c|c|}
\hline \multirow{2}{*}{ Sample } & \multicolumn{6}{|c|}{ Content (mg/g) } \\
\hline & 1 & 2 & 3 & 4 & 5 & Total \\
\hline A. koreanum from Gongju & $0.142 \pm 0.016^{d}$ & $0.957 \pm 0.011^{\mathrm{g}}$ & $1.077 \pm 0.003^{\mathrm{b}, \mathrm{c}, \mathrm{d}}$ & $0.419 \pm 0.001^{\mathrm{d}}$ & $0.318 \pm 0.007^{\mathrm{c}}$ & $2.913 \pm 0.038$ \\
\hline A. divaricatus from Gongju & $0.521 \pm 0.005^{\mathrm{a}}$ & $1.920 \pm 0.019^{\mathrm{f}}$ & $1.063 \pm 0.001^{\mathrm{c}, \mathrm{d}}$ & $0.394 \pm 0.001^{\mathrm{e}}$ & $0.500 \pm 0.003^{a}$ & $4.398 \pm 0.029$ \\
\hline A. sessiliflorus from Gongju & $0.531 \pm 0.004^{\mathrm{a}}$ & $3.517 \pm 0.079^{\mathrm{a}}$ & $1.185 \pm 0.041^{\mathrm{a}}$ & $0.501 \pm 0.010^{\mathrm{a}}$ & $0.372 \pm 0.013^{b}$ & $6.106 \pm 0.147$ \\
\hline A. senticosus from Gongju & $0.059 \pm 0.014^{\mathrm{f}}$ & $2.723 \pm 0.033^{b}$ & $1.069 \pm 0.011^{\mathrm{c}, \mathrm{d}}$ & $0.421 \pm 0.002^{\mathrm{c}, \mathrm{d}}$ & $0.264 \pm 0.003^{d}$ & $4.536 \pm 0.063$ \\
\hline A. senticosus from Jungseon & $0.107 \pm 0.011^{\mathrm{d}, \mathrm{e}}$ & $2.187 \pm 0.020^{d}$ & $1.160 \pm 0.019^{a, b}$ & $0.440 \pm 0.003^{b, c}$ & $0.187 \pm 0.001^{\mathrm{f}}$ & $4.081 \pm 0.054$ \\
\hline A. senticosus from Mt. Baekdu & $0.291 \pm 0.023^{c}$ & $2.335 \pm 0.028^{c}$ & $1.090 \pm 0.058^{\mathrm{a}, \mathrm{b}, \mathrm{c}}$ & $0.406 \pm 0.005^{\mathrm{d}, \mathrm{e}}$ & $0.179 \pm 0.003^{f}$ & $4.301 \pm 0.117$ \\
\hline A. senticosus from Khabarovsk & $0.373 \pm 0.020^{b}$ & $1.982 \pm 0.076^{\mathrm{e}}$ & $1.052 \pm 0.013^{\mathrm{c}, \mathrm{d}}$ & $0.444 \pm 0.002^{b}$ & $0.241 \pm 0.004^{\mathrm{e}}$ & $4.092 \pm 0.115$ \\
\hline Total & $2.095 \pm 0.098$ & $18.274 \pm 0.302$ & $8.715 \pm 0.178$ & $3.436 \pm 0.026$ & $2.245 \pm 0.037$ & - \\
\hline
\end{tabular}

The contents of rutin (1), hyperin (2), afzelin (3), quercetin (4) and kaempferol (5) detected in the stems and roots of Acanthopanax species were 0.856 and $2.095,9.891$ and $18.274,47.994$ and $8.715,3.601$ and $3.436,3.535$ and 2.245 $\mathrm{mg} / \mathrm{g}$, respectively. Consequently, the total content of flavonoids in the stems and roots was highest in A. senticosus from Mt. Baekdu and A. sessiliflorus from Gongju, respectively. Also, hyperin (2) and afzelin (3) were the most abundant compounds in the roots and stems of Acanthopanax species, respectively. In a previous paper, total content of flavonoids in the fruits of Acanthopanax species was highest in those of A. chiisanensis and the most abundant flavonoid in the fruits of Acanthopanax species was hyperin ${ }^{20}$. As results, among flavonoids, hyperin (2) was the most abundant compound in the roots, stems and fruits of Acanthopanax species.

Rutin (1) has been reported to prevent or delay the onset of diabetes, lower the risk of heart disease $\mathrm{e}^{21,22}$ and to have antioxidative and antihypertensive activities ${ }^{23,24}$. In addition, there are many reports on anti-inflammatory, anticancer and beneficial cardiovascular effects ${ }^{25,26}$ of hyperin (2); antimicrobial and antioxidant activities ${ }^{27}$ of afzelin (3); antiviral, anticancer and antioxidant activities ${ }^{28-30}$ of quercetin (4); and cardiovascular, neuroprotective, antidiabetic, antiosteoporotic and antiallergic activities ${ }^{31}$ of kaempferol (5).

On the basis of these results, it may be concluded that HPLC remains the method of choice for analyzing the most relevant flavonoids in Acanthopanax species. This result will be useful information in the application of these flavonoids from Acanthopanax species in the nutraceutical, pharmaceutical and cosmeceutical areas.

\section{ACKNOWLEDGEMENTS}

This work was supported by the GRRC Program of Gyeonggi Province [GRRC-CAU-2012-A01, Development of
Baemoochae Kimchi and Postharvest Technology]. The authors thank the National Center for Inter-University Research Facilities (Seoul National University, Republic of Korea) for the NMR and MS measurements. The authors specifically thank Prof. S.H. Cho, Gongju National University of Education, Korea for the generous gift of intact plants of Acanthopanax species.

\section{REFERENCES}

1. D.D. Soejarto and N.R. Farnsworth, Bot. Mus. Lealf. Harv. Univ., 26, 339 (1978).

2. C.S. Yook, Coloured Medicinal Plants of Korea. Academy Book Co., Seoul, Korea. p. 377 (1990).

3. M.K. Huh, H.W. Huh and J.S. Choi, J. Korean Soc. Hort. Sci., 46, 225 (2005).

4. N. Ni and X.Q. Liu, Chin. Tradit. Herbal Drugs, 37, 1895 (2006).

5. C. Tohda, M. Ichimura, Y.J. Bai, K. Tanaka, S. Zhu and K. Komatsu, J. Pharmacol. Sci., 107, 329 (2008).

6. B.T. Gaffney, H.M. Hügel and P.A. Rich, Med. Hypotheses, 56, 567 (2001).

7. M. Yasue, Y. Kato, Y.M. Lin and J. Sakakibara, Yakugaku Zasshi, 88, 738 (1968).

8. J. Kitajima, Y. Takamori and Y. Tanaka, Yakugaku Zasshi, 109, 188 (1989).

9. J.Y. Chung and D.R. Hanh, Yakhak Hoeji, 35, 240 (1991).

10. K. Shirasuna, M. Miyakoshi, S. Mimoto, S. Isoda, Y. Satoh, Y. Hirai, Y. Ida and J. Shoji, Phytochemistry, 45, 579 (1997).

11. S. Lee, B.K. Kim, S.H. Cho and K.H. Shin, Arch. Pharm. Res., 25, 280 (2002).

12. M. Bekker, R. Bekker and V.E. Brandt, Phytochemistry, 67, 818 (2006).

13. K.H. Shin and S. Lee, Nat. Prod. Sci., 8, 111 (2002).

14. Q. An, C.J. Yang, Y. Song, K. Yu, Z.L. Xiong and F.M. Li, Nat. Prod. Res. Dev., 20, 765 (2008).

15. E.-J. Lee, Y.-S. Jang and K.-Y. Paek, Korean J. Hort. Sci. Technol., 29, 189 (2011).

16. H.Y. Kim, D.G. Lee, K.H. Lee and S. Lee, Hort. Environ. Biotechnol., 53, 242 (2012).

17. S.-Y. Mok, J.M. Lee, H.M. Kim, D.G. Lee, Y.-H. Yoon, E.J. Cho and S. Lee, Nat. Prod. Sci., 17, 230 (2011). 
18. S. Lee, H.S. Park, Y. Notsu, H.S. Ban, Y.P. Kim, K. Ishihara, N. Hirasawa, S.H. Jung, Y.S. Lee, S.S. Lim, E.H. Park, K.H. Shin, T. Seyama, J. Hong and K. Ohuchi, Phytother. Res., 22, 1552 (2008).

19. S.-Y. Mok and S. Lee, Food Chem., 136, 969 (2013).

20. J.M. Lee, D.G. Lee, K.H. Lee, S.H. Cho, C.G. Park and S. Lee, Nat. Prod. Sci., 19, 15 (2013).

21. Y.J. Jeong, Y.J. Choi, H.M. Kwon, S.W. Kang, H.S. Park, M. Lee and Y.H. Kang, Br. J. Nutr., 93, 581 (2005).

22. M.A. Alsaif, Pak. J. Nutr., 8, 745 (2009).

23. J.S. Lee, S.J. Park, K.S. Sung, C.K. Han, M.H. Lee, C.W. Jung and T.B. Kwon, Korean J. Food Sci. Technol., 32, 206 (2000).

24. M. Holasova, V. Fiedlerova, H. Smrcinova, M. Orsak, J. Lachman and S. Vavreinova, Food Res. Int., 35, 207 (2002).
25. E. Middleton Jr., C. Kandaswami and T.C. Theoharides, Pharmacol. Rev., 52, 673 (2000).

26. J. Bernatoniene, S. Trumbeckaite, D. Majiene, R. Baniene, G. Baliutyte, A. Savickas and A. Toleikis, Phytother. Res., 23, 1701 (2009).

27. S. Tatsimo, J. Tamokou, L. Havyarimana, D. Csupor, P. Forgo, J. Hohmann, J.-R. Kuiate and P. Tane, BMC Res. Notes, 5, 158 (2012).

28. Y.B. Yu, H. Miyashiro, N. Nakamura, M. Hattori and J.C. Park, Arch. Pharm. Res., 30, 820 (2007).

29. A. Murakami, H. Ashida and J. Terao, Cancer Lett., 269, 315 (2008).

30. M.R. Hyun, Y.S. Lee and Y.H. Park, Korean J. Hort. Sci. Technol., 29, 68 (2011).

31. J.M. Calderon-Montano, E. Burgos-Moron, C. Perez-Guerrero and M. Lopez-Lazaro, Mini Rev. Med. Chem., 11, 298 (2011). 